\title{
ABSTRACT
}

This paper aims to reflect onto the scenic practice “Saudades Z(é)”, an spectacle developed from a Master's Degree research entitled "the playing-actor: the metaphoric construction of the body". This research refers to actor-researcher's memories and also alludes to the traditional play known as “Boi de Reis”, from Sítio de Santa Cruz community, Vera Cruz/RN. Throughout this work, we focus on the body of the playing actor "Zé de Moura” - who carried throughout several years the character known as Mateus in the "Boi de Reis” play. In this text, the actor-researcher presents how the process of creation "Saudades Z(é)" - a play which had as a start point the memory as a recreation of lived facts (LEONARDELLI, 2008) -, and exposes along the article how it is contaminated by the magic of the play, through the memories from the people in that location and the playing actors in the "Boi de Reis" traditional play. "Saudades Z(é)" is based in the ritual process (TURNER, 1974), to be more specific, in the concept of liminary time, and is also inspired by the theater of cruelty (ARTAUD, 1993), as a manifest scream, a plague which contaminates the playing-actor and trespasses the audience reaching their visceral organs.

Keywords: Playing-Actor: Boi de Reis Play: Creative Process: Memory: Theater 


\section{Saudades Z(é): Itinerâncias de um ator-brincante}

“Saudades Z(é)" - é um espetáculo que fala sobre as minhas memórias de quintal, que via o Boi de Reis brincar e encantar a todos da cidade de Vera Cruz/RN, memórias que me arrebataram - um espetáculo místico que homenageia um dos principais brincantes de Boi do Estado do Rio Grande do Norte - o “Mateus” Zé de Moura - um homem simples, um bom e típico homem do campo, que fez do seu terreiro, a sua brincadeira.

Quando criança, minha mãe contava histórias de Boi. Em uma das festas de reis fui vê-lo brincar, o que mais me encantava era um dos brincantes, “o Mateus” Zé de Moura, uma figura que trocava de forma rápida os pés, passando um pelo outro em um pulsar difícil de acompanhar; era lindo ver aquele homem alto, negro e magro dançar, características muitas parecidas com as minhas - tenho esse marco como ponto de partida para o terreiro da ancestralidade, investigando esse corpo que brinca e que atua, recriando nos laboratórios esse corpo brincante, que se (re)constrói no meu trabalho de ator.

Vejo nesta brincadeira, aspectos relevantes para o meu fazer, quais sejam: a preparação do corpo para cena, a relação com a plateia e os elementos constituintes da encenação, dessa maneira, faço a encruzilhada do folguedo do Boi com a cena performativa do "Saudades Z(é)" - ressalto que não é uma imitação da brincadeira, mas uma ressignificação de alguns elementos que a constituem.

O espetáculo teve como ponto inicial a memória como recriação do vivido (LEONARDELLI, 2008) -, que tem a ideia de prolongar, recriar as memórias do passado no tempo presente, permitindo que a contaminação pela magia da brincadeira, se desse não só pelas minhas memórias, mas pelas memórias do povo da referida comunidade e dos brincantes do Boi de Reis. O “Saudades Z(é)” ancora-se ainda no processo ritual (TURNER, 1974) e mais precisamente no conceito de tempo liminar, e inspira-se no teatro da crueldade (ARTAUD, 1993), como um grito manifesto, como um atravessamento desse ator-brincante.

O processo de investigação desse corpo teve início com mergulhos profundos nos laboratórios de criação - buscando incessantemente descobrir como recriar um corpo que não era o meu, no entanto, eis uma questão pedagógica do trabalho do ator: apropriar-se do lugar do outro como um lugar de representação, investigação e reflexão do e para o fazer teatral.

Assim se encaminhava a construção do espetáculo, pensamos no processo de sua elaboração a partir do estágio de criação proposto por (AMIT GOSWAMI, 2008) - que para ele, todo processo criativo se dá em quatros etapas: a preparação, a incubação, o insight e manifestação. 
Primeiro, organizei as minhas memórias de Boi, assistir vídeos do referido brincante, fiz entrevistas com os seus familiares, organizei todo o material e fui para a sala de ensaios viver o segundo momento - vivi as minhas memórias do cárcere, mas me desprendi a partir dos insights, das novas ideias que iam emergindo do corpo em processo laboratorial, estava nascendo um corpo que brinca na cena, descobrindo a partir das minhas recriações que o corpo não apenas atua, ele brinca em cena. Descobri-me ator-brincante e personagem da minha própria história.

Por fim, o “Saudades Z(é)” mostrou que é possível estabelecer um diálogo entre a teoria e a prática, que a pedagogia existente na cena, me ensinou que é preciso aprender com as manifestações culturais existentes em nossos terreiros, e que esse estado de brincadeira entre o seu e estar ator-brincante contribui de forma significativa para a minha formação enquanto artista da cena.

É está brincadeira que me faz crer na festa, na ordem social do festejo e no folguedo e sua representação como um formato de mim e parte desta cena.

ARTAUD, Antonin. O teatro e seu duplo. São Paulo: Martins Fontes, 1993.

LEONARDELLI, Patrícia. A memória como recriação do vivido. Um estudo da história do conceito de memória aplicado às artes performativas na perspectiva do depoimento pessoal. Universidade de São Paulo. São Paulo, 2008.

TURNER, Victor W. O Processo Ritual: estrutura e anti-estrutura. Trad. Nancy Campi de Castro. Petrópolis: Vozes, 1974. 